\title{
Populisme sebagai Bentuk Politik Pertahanan Pemimpin Lokal
}

\author{
Muhtar Haboddin 1 \\ Program Studi Ilmu Pemerintahan, FISIP Universitas Brawijaya, Malang - Indonesia
}

\begin{abstract}
The purpose of this article was to see how local leaders use populist policies to gain political support and maintain their power. This populist policy could be seen from the workings of several local leaders such as Jokowi while leading Jakarta and Solo, Risma in Surabaya, Ridwan Kamil in Bandung and others. To see the extent to which local leaders apply populist policy, this article used a literature-based qualitative research method and used the theory of populist leadership style as an analysis knife. Described from this article that local leaders would use populist policies in an effort to maintain power. In maintaining this power, a populist policy was needed as a strategic way to build the legitimacy of its power in the eyes of the public and politiciansin parliament.
\end{abstract}

Tujuan dari artikel ini adalah untuk melihat bagaimana para pemimpin lokal menggunakan kebijakan populis guna mendapatkan dukungan politik dan mempertahankan kekuasaannya. Kebijakan populis ini bisa dilihat dari cara kerja beberapa pemimpin lokal seperti Jokowi sewaktu memimpin Jakarta dan Solo, Risma di Surabaya, Ridwan Kamil di Bandung dan lainnya. Untuk melihat sejauh mana para pemimpin lokal mengaplikasikan kebijakan populis, maka artikel ini menggunkan metode penelitian kualitatif berbasis literature serta menggunakan teori gaya kepemimpinan populis sebagai pisau analisis. Dipaparkan dari artikel ini bahwa pemimpin lokal akan menggunakan kebijakan populis dalam usaha mempertahakan kekuasaan. Dalam mempertahankan kekuasaan tersebut dibutuhkan kebijakan populis sebagai strategis untukmembangun legitimasi kekuasaannya di mata publik dan politisi di parlemen.

Keywords: populisme; politik pertahanan; pemimpin lokal

${ }^{1}$ Korespondensi: Muhtar Haboddin (muhtar_haboddin@ub.ac.id), Jl. Veteran Malang 65141 - Indonesia. 


\section{Pendahuluan}

Pemimpin populis pada kadar tertentu dianggap sebagai sosok pahlawan (Lee 2017). Jika Antony Lee berpendapat tantang pemimpin populis, Margaret Canovan $(2000,808)$ berpendapat tentang kaum populis, di mana kaum populis menggalang dukungan melalui institusi demokrasi dengan mendekati massa yang dianggap diwakilinya. Dua kutipan di atas memberikan pemaknaan dan penilaian yang saling terkait mengenai kebijakan populisme dan pemimpin. Pemimpin populis disenangi masyarakat karena mampu memenuhi kebutuhan masyarakat dalam jangka pendek. Daya tanggap seorang pemimpin untuk mendekati masyarakat dan memenuhi keinginan atau kebutuhannya, kemudian 'dianggap sebagai sosok pahlawan' (Lee 2017).

Penilaian Lee bisa dikatakan berlebihan dalam menempatkan sosok pemimpin populis. Tetapi, dalam beberapa kasus tipe pemimpin yang disampaikan Lee menjadi nyata dalam tatakelola pemerintahan. Misalnya, gaya populis Juan Peron di Argentina pada tahun 1940-an atau populisme ala Thaksin Shinawatra, Thailand di tahun 2000-an. Tipe pemimpin populis juga ditemukan disejumlah wilayah di Tanah Air, Dkhususnya pemimpin lokal. Misalnya, Jokowi sewaktu memimpin Solo dan DKI Jakarta, Risma di Surabaya, Nurdin Abdullah di Bantaeng, Ridwan Kamil di Bandung, dan I Gede Winasa di Jembrana. Mereka adalah pemimpin yang terkenal memiliki dedikasi tinggi bekerja untuk rakyat dan mau mendengar suara rakyat.

Kehadiran para pemimpin populis ini boleh jadi bukan karena keinginannya semata, tetapi karena dipaksa oleh situasi politik. Nalar ini dipraktikkan Thaksin dalam kerangka mendapatkan dukungan politik dari masyarakat pedesaan. Karena itu, kebijakan populis merupakan instrumen bagi pemimpin politik dalam mencari dukungan dan mempertahankan kekuasaan. Dengan demikian, maka ada keterkaitan antara kebijakan populisme, politik pertahanan, dan pemimpin lokal. Tulisan ini ingin membedah keterkaitan tersebut dalam bingkai kekuasaan. Pilihan kekuasaan didasarkan pada pertimbangan bahwa kepala daerah akan menggunakan strategi kebijakan populis untuk mendapatkan dukungan politik dari masyarakat pemilih. Berangkat dari pemaparan di atas, pertanyaan adalah bagaimana pemimpin lokal menggunakan kebijakan populis untuk mempertahankan kekuasaan?

\section{Makna Populisme dan Gaya Kepemimpinan}

Populisme sangat terkait dengan gaya kepemimpinan. Secara konseptual populisme miliki banyak makna. Secara sederhana populisme dimaknai sebagai suara retorika politik, yang menganggap keutamaan dan keabsahan politik terletak pada rakyat (Anisah 2016, 99). Jadi, populisme meletakkan rakyat di atas segalanya. Pemahaman ini dilatari gagasan yang mengutamakan kepentingan rakyat. Karena itu, populisme mendapat simpatik dari masyarakat. Pendapat Richard Hofstadter, bahwa populisme membangun program-program yang membangun masyarakat (Hofstadter 1991, 132).

Pendapat lainnya, mengatakan populisme adalah sebuah ideologi yang 'tipis' yang melihat masyarakat terbagi dalam dua polarisasi homogen dan antagonistik, yakni orang-orang baik yang berhadapan dengan elit korup (Lee 2017). Populisme telah membagi antara orang baik dan orang jahat (elit korup). Orang baik dipersepsikan bisa membantu, menolong, dan menggunakan jabatannya untuk masyarakat. Sebaliknya orang jahat tidak berpihak pada rakyat dan menggunakan jabatannya untuk diri dan keluarganya. 
Sejalan dengan itu, populisme biasanya dipimpin oleh sosok karismatik yang menggunakan karisma mereka untuk menarik perhatian publik. Mereka kemudian membangun isu pentinganya mempertahankan hak rakyat kecil yang menyengsarakan rakyat (Kompas, 8 November 2017). Memperjuangkan hak rakyat kecil dan keinginan untuk mengangkat derajat manusia menjadikan politik populisme mendapatkan tempat di hati masyarakat. Oleh karena itu, populisme diyakini sebagai gaya politik yang mencakup beragam fenomena yang bisa diungkap. Setidaknya ada empat gaya populisme. Pertama, kediktatoran populis meliputi kasuskasus di mana tokoh kharismatik punya daya tarik melebihi politisi konvensional, dan mendapat kekuasaan inkonstitusional dengan memberi masyarakat 'makan dan hiburan'. Juan Peron yang dengan bantuan istrinya, Eva mampu membangun pengikut loyal di Argentina pada tahun 1940-an, adalah contoh yang jelas dari praktik kediktatoran populis.

Kedua, demokrasi populis adalah musuh representasi dan selalu berusaha mempertahankan sebanyak mungkin kekuasaan di tangan rakyat. Ciri institusionalnya yang khas adalah referendum untuk legislasi yang dihasilkan oleh dewan perwakilan; inisiatif umum, di mana pemberi suara bisa melangkahi majelis dan mengajukan undang-undang untuk ditentukan melalui pemungutan suara dalam referendum; dan lembaga recall, yakni wakil rakyat bisa dipaksa oleh konstituen mereka yang tidak puas untuk melaksanakan pemilihan ekstra sebelum akhir masa tugas mereka.

Ketiga, populisme reaksioner yang menggambarkan para politisi yang bermain-main dengan prasangka massa dalam negara-negara demokrasi untuk melawan pandangan-pandangan yang telah dianggap lebih cemerlang dari elit politik. Para politisi yang mendapat popularitas dengan mempermainkan permusuhan etnis atau pandangan sayap kanan mengenai ketertiban umum paling mudah dituding sebagai populisme dalam pengertian ini. Keempat, populisme kaum politisi adalah politisi yang menghindari komitmen ideologis dan mengklaim berbicara atas nama rakyat secara keseluruhan, bukan untuk faksi tertentu, serta gaya partai 'untuk semua orang' yang prinsipnya tidak banyak, kebijakannya luwes dan siap menerima semua pendatang (Canovan 2000, 807). Karena itu, populisme merupakan ekspresi dari kehendak umum (Lee 2017).

\section{Kebijakan Populisme dan politik pertahanan}

Kebijakan populis sangat terkait dengan politik pertahanan kepala daerah. Politik pertahanan yang dimaksud adalah upaya kepala daerah menggunakan kuasanya dalam rangka mendapatkan dukungan politik agar tetap berkuasa. Kekuasaan adalah kemampuan untuk mengerahkan sumberdaya guna mencapai tujuan pemimpin (Huntington 1983, 219). Salah satu tujuan pemimpin adalah mempertahankan kekuasaannya. Dalam usaha mempertahankan kekuasaannya, maka program-program populis yang bersentuhan langsung dengan masyarakat secara umum perlu disebarkan dan dibagi-bagi. Adapun program populis yang menyangkut kepentingan publik tergambar dari hasil riset Power, Walfare and Democracy (PWD) (Savirani, Tornquist, dan Stokke 2014. 10). Untuk lebih jelasnya bisa dilihat pada Grafik 1 .

Pada grafik 1. memperlihatkan bahwa kebijakan populis yang paling penting bagi masyarakat menyangkut isu publik yang berkaitan dengan pelayanan publik sudah mencapai 55 persen. Sedangkan isu yang menyangkut pembangunan ekonomi sebanyak 28 persen. 


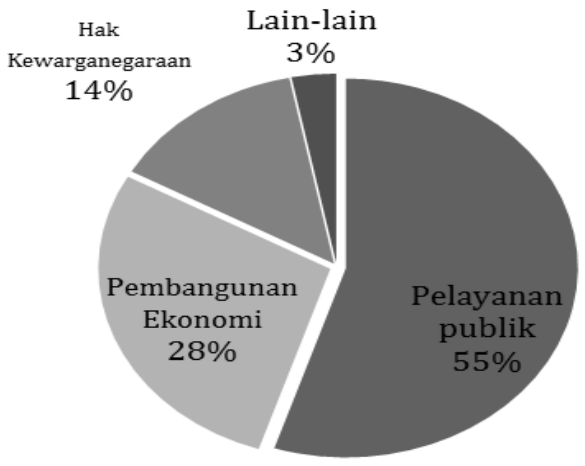

Grafik 1. Prioritas Program Populis

Sumber: PWD, 2014:10

Sisanya menyangkut hak kewarganegaraan 14 persen dan lain-lainnya 3 persen. Bila dicermati grafik tersebut, pelayanan publik dan pembangunan ekonomi menempati urutan teratas karena merupakan isu pokok yang bersentuhan langsung dengan kebutuhan masyarakat. Maka, pemimpin memberikan perhatian khusus pada kebijakan tersebut sebagai cara untuk mencari dukungan rakyat melalui kebijakan-kebijakan populis. Strategi ini tidak memerlukan pengorganisasian gerakan rakyat atau dukungan partai-politik yang kuat sebagai instrumen demokrasi, namun lebih bergantung pada upaya individual pemimpin (Savirani 2016, 74).

Kebijakan populis sangat tergantung pada upaya pemimpin daerah tanpa memerlukan dukungan organisasi massa dan partai politik. Maksudnya adalah kebijakan populis sengaja dipilih sebagai bentuk keberpihakannya kepada masyarakat. Keberpihakan itu disuarakan sejak masa kampanye hingga menjadi pejabatsebagaimana ditulis Amalinda bahwa para pemimpin lokal cenderung menggunakan isu-isu populis selama masa kampanye atau pun sedang berkuasa. Misalnya, mereka cenderung mempromosikan secara terus menerus kebijakan-kebijakan yang berkaitan dengan kesejahteraan publik seperti jaminan kesehatan dan pendidikan gratis (Savirani 2016, 74).

Jaminan kesehatan gratis dan pendidikan gratis merupakan dua kebijakan paling populis yang diperlukan oleh masyarakat petani, buruh, nelayan, dan kaum miskin kota karena menjadi kebutuhan dasar. Maka dari itu, pemimpin lokal berusaha memenuhinya. Akan tetapi, dibalik kebijakan populis, pemimpin lokal mengambil manfaat dan keuntungan politik dalam bentuk; pertama, ingin menegaskan bahwa pemimpin memiliki integritas pribadi yang menyatukan satu kata dan perbuatan. Pemimpin dipegang dari ucapannya dan teruji dalam perbuatannya (Effendi 2012,304). Karena itu, apa yang menjadi kampanye politiknya akan ditindaklanjuti pada saat menjabat. Biasanya, program-program populis yang ditawarkan pemimpin lokal berkaitan dengan kesejahteraan dan layanan publik.

Kedua, ingin mencitrakan bahwa kekuasaan itu digunakan untuk menyejahterakan masyarakat. Kekuasaan yang menyejahterakan masyarakat merupakan pilihan rasional bagi pemimpin dalam membangun kekuasaan di tingkat lokal. Sebagaimana dikatakan Samuel Huntington bahwa memperluas kesejahteraan keseluruh wilayah merupakan bagian dari pembangunan 
kekuasaan dan perluasan pengaruh kekuasaan dalam masyarakat (Huntington 1983, 224). Karena itu, mendistribusikan kesejahteraan ke seluruh wilayah sangat penting guna memperkokoh kekuasaan pemimpin. Dengan kata lain, kekuasaan diperuntukkan untuk kebajikan bersama.

Ketiga, kebijakan populis akan menciptakan hubungan yang semakin dekat antara pemimpin dengan masyarakat. Kedekatan antara pemimpin dan masyarakat dibangun melalui kebijakan promasyarakat. Pemimpin yang baik selalu merespon kebutuhan masyarakat, memberikan perlindungan, dan memberikan kesejahteraan. Dengan cara ini, maka loyalitas masyarakat akan terbangun secara solid. Loyalitas masyarakat dibangun melalui kedekatan, perlindungan dan kesejahteraan. Implikasinya adalah pemimpin mendapatkan pengakuan karena memberikan keteladanan nyata kepada masyarakat.

Keempat, kebijakan populis akan mendapatkan legitimasi dari masyarakat. Legitimasi akan membuka kesempatan yang semakin luas bagi pemimpin untuk tidak hanya memperluas bidang-bidang kesejahteraan dan pelayanan publik, tetapi juga perlu peningkatan kualitas. Peningkatan kualitas berarti peningkatan pengawasan atas penggunaan kewenangan (Surbakti 1992, 99). Kewenangan merupakan kekuasaan yang memiliki keabsahan dalam menjaga kualitas kesejahteraan dan pelayanan publik yang baik.

\section{Populisme: Belajar dari Daerah}

Populisme tumbuh dan berkembang di daerah dalam beberapa tahun terakhir. Catatan sejumlah pengamat menyebutkan bahwa Jokowi di Solo dan I Gede Winasa di Jembrana adalah pemimpin pionir yang mengusung kebijakan populis. Jembrana yang miskin mampu disulap menjadi daerah sejahtera. Pendidikan dan kesehatan dinikmati secara gratis oleh seluruh masyarakat Jembrana. Kepala Daerah Jembrana dikenal sebagai pemimpin yang berpihak terhadap kepentingan masyarakat miskin. Selain itu, pemimpinnya pun dikenal secara luas memiliki komitmen dalam mempromosikan kesejahteraan (Eko 2007, 60).

Citra pemimpin populis terus bermuncul di daerah. Menariknya adalah mereka menjadi kepala daerah tanpa ada hubungannya dengan Orde Baru. Namun demikian, mereka memiliki karakteristik yang sama. Siapa mereka?

Walikota Surabaya Tri Risma Harini, Walikota Bandung Ridwan Kamil, Bupati Bantaeng Nurdin Abdullah dan Bupati Bojonegero Suyono. Para pemimpin ini merepresentasikan orientasi yang relatif sama yang menganggap kepemimpinan sebagai sebuah kewajiban untuk bekerja demi publik. Mereka juga membangun citra sebagai para pemimpin untuk melayani masyarakat dan tidak terhubung dengan oligarki-oligarki Orde Baru. Keberhasilan mereka dalam membangun politiknya ditopang oleh kredibilitas sendiri (Savirani 2016, 68-9).

Ada dua catatan yang bisa ditarik dari kutipan di atas. Pertama, pemimpin lokal bekerja demi rakyat dan melayani masyarakat sepenuh hati. Pemimpin sebagai pelayan publik merupakan citra yang sudah menempel pada sosok Risma, Kamil, Nurdin, dan Suyono. Kedua, pemimpin lokal ini tumbuh dengan mengandalkan kapasitas individual. Kapasitas individual dioptimalkan dalam rangka memunculkan karakter kepemimpinan yang kuat, dimana pengaruhnya tidak hanya mendominasi birokrasi daerah, tetapi juga bisa mempengaruhi lembaga legislatif. Karena itu, keberadaan figur yang kuat sangat berperan dalam mentransformasi isu publik ke dalam agenda kebijakan, sehingga pada saat yang sama menguatkan politik yang berbasis individual (Paskarina, Asiah, dan Madung 2016, 45) atau biasa disebut politik berbasis figur.

Politik yang berbasis figur telah mewarnai politik lokal. Pertama, telah muncul banyak sosok 
kepala daerah yang mampu menjawab harapan masyarakat. Para kepala daerah hadir dengan sejumlah program-program populitis, inovatif, dan progresif di masa kini. Kedua, menguatnya politik berbasis figur, hadir setelah penerapan sistem pemilihan langsung. Mereka terpilih menjadi pemimpin menjalin hubungan langsung dengan masyarakat. Sosoknya yang dekat dengan masyarakat, lazim disebut pemimpin populis. Pemimpin populis ini juga mampu melakukan inovasi dan pembaharuan pemerintahan daerah. Ketiga, pemimpin populis, tidak jarang dinilai kontroversial ketika membuat kebijakan dan berani berhadapan dengan partai pengusungnya di DPRD ketika kebijakannya tidak disetujui partai politik dan DPRD. Keberanian ini muncul karena kualitas personalnya yang didukung dengan kemampuannya mengelola sumberdaya politik, sosial dan ekonomi yang demikian besar (Paskarina, Asiah, dan Madung 2016, 89-0).

\section{Empat Tantangan Populisme di Aras Lokal}

Populisme memberikan warna baru dalam dinamika politik dan kekuasaan di tingkat lokal. Pemimpin lokal dalam mempertahankan kekuasaannya dituntut untuk pandai menggagas program-program populis dan mengontrol kesejahteraan publik. Kemampuan pemimpin populis dalam mempromosikan program populis dan mengontrol kesejahteraan merupakan strategi dalam memperkokoh kekuasaannya. Implikasinya adalah memunculkan personal yang kuat di tingkat lokal—dan dalam batas tertentu berani melawan partai politik dan DPRD dengan mengatasnamakan kepentingan rakyat Atas nama 'rakyat' dan 'kepentingan rakyat' bisa menjadi senjata bagi pemimpin populis untuk melawan musuh politiknya.

Pemimpin populis perlu diwaspadai karena empat hal. Pertama, jika pemerintahan dikuasai dengan pemimpin populis, dampaknya bisa memundurkan demokrasi (Kompas, 8 November 2017). Karena pemimpin populis lebih percaya pada rakyat pemilih sebagai basis kekuasaan ketimbang lembaga demokrasi yang direpresentasikan DPRD. Mengabaikan lembaga DPRD dalam tatakelola pemerintahan daerah sudah tentu tidak dibenarkan, kerena kepala daerah dan DPRD merupakan bagian dari penyelenggara pemerintah daerah (UU 23 Tahun 2014 pasal 57).

Kedua, pemimpin populis bisa muncul karena lemahnya partai politik. Pemimpin-pemimpin yang dikenal masyarakat karena inovasinya, pembaharuan tata kelola pemerintah, sehingga program populis dalam bentuk pelayanan publik dan kesejahteraan adalah pemimpin yang lahir di luar rahim partai politik. Nurdin Abdulla di Bantaeng berlatarbelakang akademisi dan penguasa, Ridwan Kamil berlatarbelakang tokoh muda aktivis sosial dan arsitek tatakota, Tri Risma adalah birokrat, dan figur Jokowi di Solo dan DKI Jakarta adalah pengusaha. Karena mereka tidak lahir dari rahim partai politik, maka mereka membesarkan dirinya melebihi partai politik. Implikasinya adalah partai politik hanya menjadi instrumen bagi mereka untuk meraih kekuasaan.

Bila hal ini terus dibiarkan, maka marginalisasi peran partai politik semakin mengecil. Fenomena ini tentu sangat membahayakan eksistensi partai politik sebagai tempat lahirnya kaderisasi kepemimpinan. Sepanjangan partai politik gagal melahirkan kader atau pemimpin, sudah barang tentu para pemimpin populis akan mengambil manfaat dari kelemahan partai politik.

Ketiga, pemimpin populis akan menghadapi situasi ketidakberlanjutan program-programnya. Hal ini bisa terjadi karena program-program populis biasanya diciptakan dengan bersandar kemauan pemimpinnya dalam merespon 
keinginan masyarakat. Program populis biasanya jangka pendek. Jadi, ketika kepala daerah ganti sudah otomatis semua program-program populis juga runtuh seketika. Inilah yang menjadi kelemahan terbesar dari pemimpin populis karena tidak melembagakan program-program populis secara jangka panjang.

Keempat, bila ditarik secara global, politik populis cenderung pada gaya menghasut dan sering menggalang dukungan massa-rakyat untuk kepentingan politik pemimpin. Catatan Canovan, menyebutkan bahwa kaum populis menggalang dukungan melalui institusi demokrasi dan politisi dengan mendekati massa yang dianggap diwakilinya. Untuk melakukan itu, mereka memanfaatkan kata rakyat. Di Inggris, rakyat berhadapan dengan faksi-faksi yang bertikai, rakyat berhadapan dengan orang kaya dan kuat, rakyat biasa berhadapan dengan polisi profesional; dan rakyat kita berhadapan dengan orang asing atau etnis minoritas (Canovan 2000, 808).

Empat tantangan kebijakan populisme membuktikan kemahiran pemimpin populis dalam membangun kekuasaannya. Programprogram populis yang selama berkuasa diluncurkan menjadi instrumentasi dalam mempertahankan kekuasaan. Selebihnya bisa dibaca sebagai strategi untuk mendapatkan legitimasi politik karena mampu memberikan kesejahteraan dan pelayanan publik yang baik kepada masyarakat. Legitimasi dan pengakuan dari masyarakat semakin membesarkan citra dirinya sebagai pemimpin pro rakyat dan pemurah. Citra inilah kemudian melekat dalam pemimpin populis di tingkat lokal.

\section{Simpulan}

Pemimpin lokal akan menggunakan kebijakan populis dalam usaha mempertahakan kekuasaan. Dalam mempertahankan kekuasaan membutuhkan kebijakan populis sebagai strategi untuk membangun legitimasi kekuasaannya di mata publik dan politisi di parlemen. Kebijakan populis yang paling dibutuhkan masyarakat adalah kesejahteraan dan pelayanan publik berupa pendidikan dan kesehatan. Dalam rangka memenuhi kebutuhan tersebut, pemimpin lokal akan berusaha memaksimalkan dana pemerintah untuk membiayai program-program tersebut

Hal ini sengaja dilakukan untuk menunjukkan bahwa pemerintah bekerja untuk rakyat dan kekuasaan digunakan untuk menghasilkan program-program populis. Karena itu, kekuasaan harus mengontrol semua sumberdaya sekaligus mendistribusikannya kepada semua warga tanpa diskriminatif. Pada titik inilah, Goodwyn mengatakan: populisme bersifat ekspansif dan bernafsu. Namun yang terpenting ialah bahwa populisme itu mempertinggi tekad untuk berjuang demi umat manusia (Goodwyn 1991, 159). Dengan demikian beberapa pemimpin populis berusaha mengadakan perubahan yang manusiawi di dalam peri kehidupan masyarakat lokal ((Hofstadter 1991, 132). Karena itu, kebijakan populisme akan tetap menjadi pilihan rasional bagi pemimpin lokal yang ingin mempertahankan kekuasaannya.[]

\section{Daftar Pustaka}

Anisah, Laili Nur. 2016. “Tri Rismaharini: Wajah Pemimpin Populis Indonesia.” In Berebut kontrol atas kesejahteraan: Kasus-kasus politisisasi demokrasi di tingkat lokal, ed. Caroline Paskarina, Mariatul Asiah, dan Oto Gusti Madung. Yogyakarta: PolGov (Research Centre for Politics and Government, Department of Politics and Government, 
Fisipol UGM) dan PCD Press.

Canovan, Margaret. 2000. “Populisme.” In The Social Science Encyclopedia, ed. Adam Kuper dan Jessica Kuper. Jakarta: RajaGrafindo Persada.

Effendi, Djohan. 2012. Pesan-pesan al-Quran. Jakarta: Serambi.

Eko, Sutoro. 2007. “Dari Daerah Budiman menuju Daerah Sejahtera.” Mandatory 3(3).

Goodwyn, Lawrance. 1991. "Populisme: Janji Demokratis." In Konflik dan Konsensus, ed. Allen F. Davis dan Harold D. Woodman. Yogyakarta: Universitas Gadjah Mada Press.

Hofstadter, Richard. 1991. "Populisme: Nostalgia Agraris.” In Konflik dan Konsensus, ed. Allen F. Davis dan Harold D. Woodman. Yogyakarta: Universitas Gadjah Mada Press.

Huntington, Samuel P. 1983. Tertib Politik dalam Masyarakat yang Sedang Berubah. Jakarta: Rajawali Press.

Lee, Antony. 2017. “Kepahlawanan dalam Intipan Populisme.” Kompas.

Paskarina, Caroline, Mariatul Asiah, dan Otto Gusti Madung. 2016. Berebut kontrol atas kesejahteraan: Kasus-kasus politisisasi demokrasi di tingkat lokal. Yogyakarta: PolGov (Research Centre for Politics and Government, Department of Politics and Government, Fisipol UGM) dan PCD Press.

Savirani, Amalinda. 2016. "Negara, Bisnis yang Terkonsolidasi, dan Pemimpin Populis Baru." In Reclaiming The State, ed. Amalinda Savirani dan Olle Tornquist. Yogyakarta: PolGov (Research Centre for Politics and Government, Department of Politics and Government, Fisipol UGM) dan PCD Press.

Savirani, Amalinda, Olle Tornquist, dan Kristin Stokke. 2014. Demokrasi di Indonesia: Antara Patronase dan Populisme. Yogyakarta: Universitas Gadjah Mada dan University of Oslo.

Surbakti, Ramlan. 1992. Memahami Ilmu Politik. Jakarta: Grasindo. 